\title{
Airways obstruction associated with graft versus host disease after bone marrow transplantation
}

\author{
SE WYATT, P NUNN, JM HOWS, JAL YIN, MC HAYES, D CATOVSKY, \\ EC GORDON-SMITH, JMB HUGHES, JM GOLDMAN, DAG GALTON
}

From the Medical Research Council Leukaemia Unit and the Departments of Haematology, Medicine, and Histopathology, Royal Postgraduate Medical School, Hammersmith Hospital, London

ABSTRACT Eight patients, five with chronic granulocytic leukaemia and three with severe aplastic anaemia, developed moderately severe airflow obstruction after allogeneic bone marrow transplantation. All eight had clinically and radiologically normal lungs before undergoing transplantation. Treatment in the patients with chronic granulocytic leukaemia before transplantation included high dose total body irradiation. All eight patients developed acute and chronic graft versus host disease after transplantation. The pulmonary syndrome consisted of cough, dyspnoea, and wheezing beginning six to 20 weeks after transplantation, with ratios of forced expiratory volume in one second $\left(\mathrm{FEV}_{1}\right)$ to vital capacity (VC) falling to $60 \%$ or less of predicted values. The three patients with severe aplastic anaemia had relatively mild graft versus host disease and acute chest infection may have initiated or contributed to their airways obstruction, which subsequently resolved. The five patients with chronic granulocytic leukaemia had more severe graft versus host disease and more progressive respiratory problems; two died and three continued to have persistent airflow obstruction 11, 15, and 20 months after transplantation. None of those with chronic granulocytic leukaemia improved. Transfer factor (TLCO) was reduced in all patients after bone marrow transfer and did not improve; in the patients with chronic granulocytic leukaemia the reduction in TLCO preceded the fall in $\mathrm{FEV}_{\mathrm{l}} / \mathrm{VC}$ ratio. Open lung biopsy in one of the patients with chronic granulocytic leukaemia showed obliterative bronchiolitis with lymphocytic infiltration consistent with graft versus host disease. Bronchodilators were of no benefit in the management of these patients, but prompt treatment of infection and early use of corticosteroids may have contributed to the improvement seen in the patients with severe aplastic anaemia.

Allogeneic bone marrow transplantation is used in the treatment of patients with aplastic anaemia and acute and chronic myeloid leukaemias. ${ }^{12}$ Pulmonary complications are, however, a major source of morbidity and death in patients undergoing transplantation. Opportunistic infections with viruses, fungi, and protozoa are common. ${ }^{3}$ An interstitial pneumonitis in the absence of evidence of infection also occurs, particularly in those who have received higher doses (>8 Gy (800 rad)) and dose rates of

Address for reprint requests: Dr J M Goldman, MRC Leukaemia Unit, Royal Postgraduate Medical School, Hammersmith Hospital, London W12 0HS.

Accepted 11 June 1984 total body irradiation. ${ }^{45}$ Chronic graft versus host disease has been associated with interstitial pneumonia, ${ }^{3}$ lymphocytic bronchitis, ${ }^{6}$ late respiratory tract infections, and both obstructive and restrictive lung disease. ${ }^{7}$ Seven patients have recently been reported in whom severe obstructive lung disease after bone marrow transplantation was attributed to chronic graft versus host disease; it proved fatal in three cases. ${ }^{8-10}$

We report on eight patients, three undergoing transplantation for severe aplastic anaemia and five for chronic granulocytic leukaemia, who developed a pulmonary syndrome consisting of cough, dyspnoea, and wheezing with moderate to severe airways obstruction concomitant with chronic graft versus host disease. 


\section{Methods}

Between January 1979 and July 1983, 48 patients with severe aplastic anaemia and 37 with chronic granulocytic leukaemia received allogeneic bone marrow transplants from first degree relatives. The eight patients reported on here and their respective donors were identical for HLA antigens and nonreactive in mixed lymphocyte culture. Before transplantation patients with severe aplastic anaemia received four doses of cyclophosphamide $50 \mathrm{mg} / \mathrm{kg}$, and those with chronic granulocytic leukaemia a single dose of daunorubicin $60 \mathrm{mg} / \mathrm{m}^{2}$, two doses of cyclophosphamide $60 \mathrm{mg} / \mathrm{kg}$, and total body irradiation with a Philips $8 \mathrm{MeV}$ linear accelerator to a total of $10 \mathrm{~Gy}(1000 \mathrm{rad})$ in $2 \mathrm{~Gy}(200 \mathrm{rad})$ fractions at a dose rate of $15 \mathrm{cGy}(15 \mathrm{rad}) / \mathrm{min}$. Treatment with cyclosporine was started on the day before bone marrow transplantation as prophylaxis against graft versus host disease and also as immunosuppression for patients with severe aplastic anaemia. It was continued for at least six months. When acute graft versus host disease was diagnosed clinically it was usually confirmed by biopsy and was graded by the criteria of Thomas et al. "It was treated with methylprednisolone, $1-20 \mathrm{mg} / \mathrm{kg} / \mathrm{day}$, according to severity. Prednosolone and azathioprine were used in the treatment of chronic graft versus host disease.

Respiratory symptoms, a personal or family history of atopy, and smoking history were recorded for each patient before treatment. Chest radiographs were taken before transplantation and at regular intervals thereafter. The following variables of lung function were tested in the laboratory using standard methods: forced expiratory volume in one second $\left(\mathrm{FEV}_{1}\right)$, vital capacity (VC), single breath carbon monoxide transfer factor (TLCO), alveolar volume (VA), total lung capacity (TLC), and residual volume $(\mathrm{RV})$. Normal ranges were obtained from Quanjer (volumes) ${ }^{12}$ and Bradley et al (TlCO, KCO). ${ }^{13}$ The TLCO and $\mathrm{KCO}$ values were corrected from the current haemoglobin concentration to a standard value of $14.6 \mathrm{~g} / \mathrm{dl} .{ }^{14}$ Serum viral antibody titres were measured monthly in all patients, and viral and microbiological cultures were performed when appropriate.

\section{PATIENTS WITH CHRONIC GRANULOCYTIC LEUKAEMIA}

Table 1 gives details of the five patients with chronic granulocytic leukaemia. They developed acute graft versus host disease of skin, liver, and gut progressing to severe chronic mucocutaneous graft versus host disease, which required long term immunosuppressive treatment.

Cases 1 to 3 These patients pursued a similar

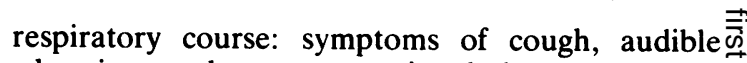
wheezing, and severe exertional dyspnoea begano eight to 20 weeks after bone marrow transplanta- $\overline{0}$ tion. Auscultation showed scattered wheezes in all $\frac{\bar{\sigma}}{\overline{1}}$ three patients and basal crackles in two (cases 1 and $\mathbb{\varnothing}$ 2). These two patients remained quite severely@ handicapped by dyspnoea 15 and 20 months after bone marrow transplantation. Symptoms improved? in one patient (case 3 ) so that only mild exertional $\overrightarrow{\vec{\omega}}$ dyspnoea was present 11 months after bone marrow transplantation. Chest radiographic appearances $\overrightarrow{\times}$ remained normal throughout the respiratory illness, $\omega$ and viral and bacteriological screening tests repeatedly yielded negative results in all three $\overrightarrow{0}$ patients. Treatment with inhaled bronchodilators $\stackrel{\infty}{\infty}$ was of no benefit.

Case 4 This patient developed cough and dys- $\stackrel{\circ}{?}$ pnoea beginning six weeks after bone marrow trans- $\vec{\square}$ plantation. Her dyspnoea became severe at rest, and $\Phi$ auscultation showed expiratory wheezes and basal $\Phi$ crackles. The chest radiograph remained normal훙 until three months after bone marrow transplanta- $\frac{\mathbb{Q}}{-}$ tion, when bilateral patchy shadowing was noted. $\overrightarrow{0}$ This peristed until her death three weeks later from $\stackrel{\infty}{+}$ a pseudomonas septicaemia. Open lung biopsy was performed three months after bone marrow transplantation. Histological examination showed lymphocytic infiltration of the terminal bronchiolar walls and fibrous obliteration of bronchiolar lumina $\stackrel{\odot}{\triangle}$ (fig 1). No organism was isolated.

Case 5 This patient also developed cough and exertional dyspnoea six weeks after bone marrow transplantation. At 21 weeks after bone marrow transplantation he developed staphylococcal pneumonia with left lower lobe collapse. His dyspnoea progressed despite eradication of the organism after antibiotic treatment. Later Branhamella ${ }_{-}^{\times}$ catarrhalis was isolated from purulent sputum. The 3 left lower lobe collapse persisted. He subsequently required assisted ventilation and died of aspergillus pneumonia six months after bone marrow transplan- $\mathrm{o}$ tation.

PATIENTS WITH SEVERE APLASTIC ANAEMIA These three patients developed acute graft versus $\mathscr{N}$ host disease progressing to mild or moderate chronic N graft versus host disease.

Case 6 This patient developed a cough and severe exertional dyspnoea with bilateral crackles and wheezes audible in the chest six weeks after bone? marrow transplantation. Chest radiographic appear- $\stackrel{D}{\rightarrow}$ ances were normal. Her condition improved with antibiotic and steroid treatment, but the dyspnoea 0 and auscultatory findings persisted. She was aळ smoker (table 1) and continued to smoke, though at a reduced level, after bone marrow transplantation. 

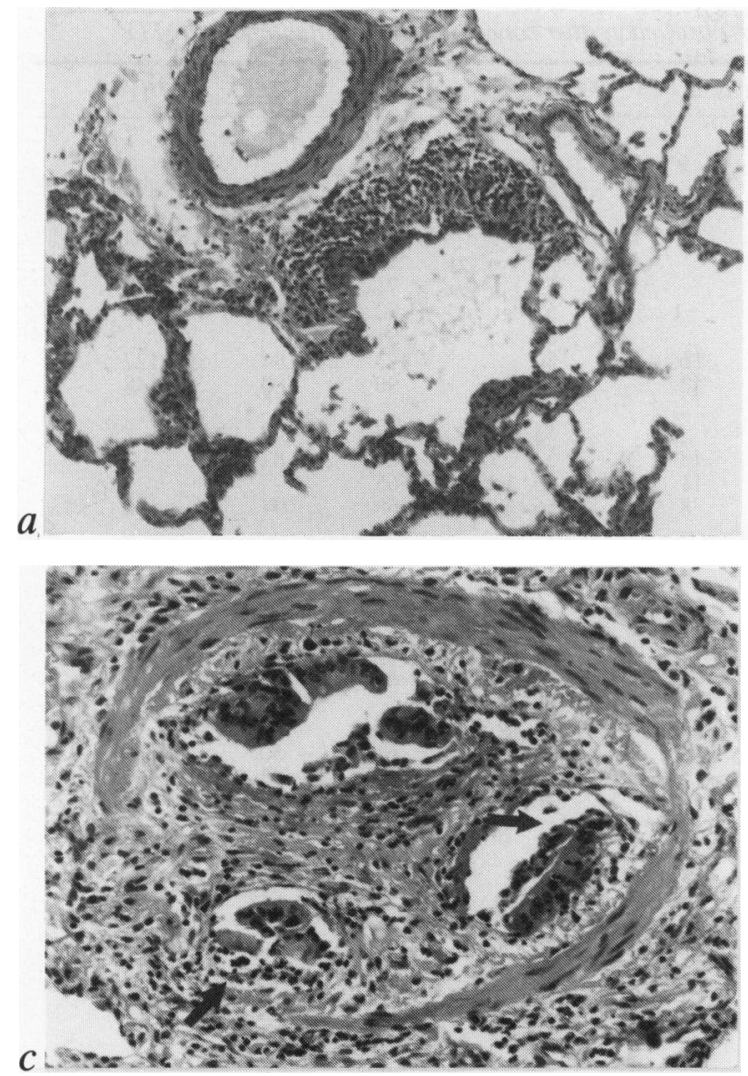

Her symptoms had resolved one year later.

Case 7 This patient had received 6 Gy $(600 \mathrm{rad})$ total body irradiation in addition to cyclophosphamide before bone marrow transplantation. He developed features suggestive of a chest infection with bilateral basal consolidation soon after transplantation. This resolved with antibiotic treatment.

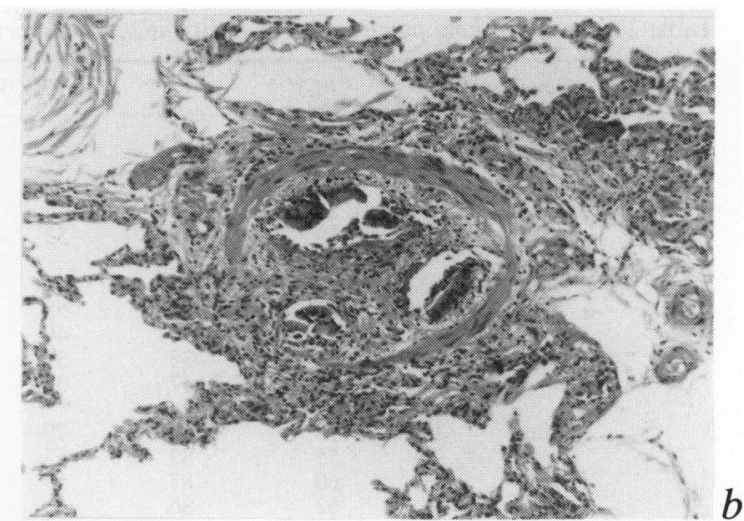

Fig 1 Histological appearances of open lung biopsy specimen in case 4 performed three months after bone marrow transplantation showing: (a) Lymphocytic infiltration of a respiratory bronchiolar wall. The surrounding alveoli are normal. (Haematoxylin and eosin, $\times 80$.) (b) and (c-a close up of (b)) Obliteration of bronchiolar lumen by granulation tissue with residual islands of normal respiratory epithelium (arrows); the normal surrounding alveoli are again seen. (Haematoxylin and eosin, $\times 65$ and $\times 150$.)

Later, when chest radiographic appearances were normal, cough and scattered wheezes developed. Improvement occurred with antibiotic and steroid treatment, but symptomatic wheezes were still present six months after bone marrow transplantation. Case 8 Graft versus host disease followed a similar course in this patient, with left basal consolidation

Table 1 Clinical features of eight patients with airways obstruction after bone marrow transplantation (BMT)

\begin{tabular}{|c|c|c|c|c|c|c|c|c|c|c|}
\hline $\begin{array}{l}\text { Case } \\
\text { Vo }\end{array}$ & Age & $\operatorname{Sex}$ & Disease & $\begin{array}{l}\text { Smoking } \\
\text { (cigarettes } \\
\text { per day) }\end{array}$ & Atopy & $\begin{array}{l}\text { Acute } \\
\text { GVHD } \\
\text { (grade) }\end{array}$ & Chronic GVHD & $\begin{array}{l}\text { Onset of } \\
\text { respiratory } \\
\text { symptoms } \\
\text { (weeks after } \\
\text { BMT) }\end{array}$ & $\begin{array}{l}\text { Drug } \\
\text { treatment }\end{array}$ & Outcome \\
\hline 1 & 18 & $\mathbf{F}$ & CGL & 20 & & II & Severe, improving & 8 & $\mathbf{P}, \mathbf{A}, \mathbf{S}$ & $\begin{array}{l}\text { Symptoms moderate, severe at } 15 \\
\text { months }\end{array}$ \\
\hline 2 & 23 & $\mathbf{F}$ & CGL & 20 & Eczema & II & Severe, worsening & 17 & $\mathbf{P}, \mathbf{A}, \mathbf{S}$ & $\begin{array}{l}\text { Symptoms severe and worsening at } \\
20 \text { months }\end{array}$ \\
\hline $\begin{array}{l}3 \\
4\end{array}$ & $\begin{array}{l}20 \\
16\end{array}$ & $\begin{array}{l}\mathbf{M} \\
\mathbf{F}\end{array}$ & $\begin{array}{l}\text { CGL } \\
\text { CGL }\end{array}$ & $\begin{array}{l}\mathbf{0} \\
\mathbf{0}\end{array}$ & & III & $\begin{array}{l}\text { Severe, improving } \\
\text { Severe }\end{array}$ & $\begin{array}{r}20 \\
6\end{array}$ & $\begin{array}{l}\text { P,A,S } \\
\text { P,AL,Ab, } \\
\text { AF }\end{array}$ & $\begin{array}{l}\text { Symptoms mild at } 11 \text { months } \\
\text { Died of septicaemia at } 4 \text { months }\end{array}$ \\
\hline 5 & 33 & $\mathbf{M}$ & CGL & $\mathbf{0}$ & & IV & Severe & 6 & P,A,S, Ab, & Died of respiratory illness at 6 months \\
\hline $\begin{array}{l}6 \\
7\end{array}$ & $\begin{array}{l}30 \\
14\end{array}$ & $\begin{array}{l}\mathbf{F} \\
\mathbf{M}\end{array}$ & $\begin{array}{l}\text { SAA } \\
\text { SAA } \\
\text { (Fanconi) }\end{array}$ & $\begin{array}{r}25 \\
0\end{array}$ & & $\begin{array}{l}\text { III } \\
\text { III }\end{array}$ & $\begin{array}{l}\text { Mild, resolved } \\
\text { Mild, resolved }\end{array}$ & $\begin{array}{r}6 \\
11\end{array}$ & $\begin{array}{l}\text { P,S,Ab } \\
\mathbf{P}, \mathbf{S}, \mathrm{Ab}\end{array}$ & $\begin{array}{l}\text { Symptoms resolved by } 12 \text { months } \\
\text { Symptoms resolved by } 6 \text { months }\end{array}$ \\
\hline 8 & 26 & $\mathbf{M}$ & SAA & $\mathbf{0}$ & Hay fever & II & Mild, resolved & 8 & $\mathbf{P}, \mathbf{S}, \mathbf{A b}$ & Symptoms resolved by 6 months \\
\hline
\end{tabular}

CGL_chronic granulocytic leukaemia; GVHD—graft versus host disease; P-prednisolone; A-azathioprine; S-salbutamol; Ab-antibiotics; $\mathrm{AF}$-antifungals; $\mathrm{AL}$-antilymphocyte globulin. 
Table 2 Resuls of hung function tests in eight patients with airways obstruction after bone manow transplantation (BMT)

\begin{tabular}{|c|c|c|c|c|c|c|c|c|c|c|}
\hline \multirow{2}{*}{$\frac{\text { Case No }}{1}$} & \multicolumn{2}{|c|}{ Time (weeks) } & \multirow{2}{*}{$\begin{array}{l}F E V_{1}^{*} \\
91 \\
32 \\
26 \\
26 \\
29\end{array}$} & \multirow{2}{*}{$\begin{array}{l}V C^{*} \\
84 \\
58 \\
56 \\
53 \\
48\end{array}$} & \multirow{2}{*}{\multicolumn{2}{|c|}{$\begin{array}{lc}F E V / V C(\%) & \Delta F E V_{1}(\%) \\
96 & 5 \\
49 & 20 \\
42 & 7 \\
44 & 9\end{array}$}} & \multirow{2}{*}{$\begin{array}{l}\text { TLCO* } \\
94 \\
66 \\
58 \\
58 \\
64\end{array}$} & \multirow{2}{*}{$\begin{array}{r}K C O^{*} \\
107 \\
98 \\
94 \\
105 \\
108\end{array}$} & \multirow{2}{*}{$\begin{array}{l}T L C^{*} \\
82 \\
84\end{array}$} & \multirow{2}{*}{$\begin{array}{l}R V^{*} \\
200 \\
184\end{array}$} \\
\hline & $\begin{array}{l}\text { Before } \\
\text { After }\end{array}$ & $\begin{array}{l}\text { BMT } \\
26 \\
39 \\
52 \\
65\end{array}$ & & & & & & & & \\
\hline 2 & After & $\begin{array}{l}13 \\
24 \\
36 \\
65 \\
82\end{array}$ & $\begin{array}{l}78 \\
31 \\
27 \\
24 \\
20\end{array}$ & $\begin{array}{l}91 \\
58 \\
40 \\
35 \\
57\end{array}$ & $\begin{array}{l}91 \\
58 \\
40 \\
35 \\
32\end{array}$ & $\begin{array}{r}-1 \\
16 \\
2\end{array}$ & $\begin{array}{l}53 \\
55 \\
62 \\
50 \\
55\end{array}$ & $\begin{array}{l}71 \\
92 \\
91 \\
73 \\
90\end{array}$ & $\begin{array}{l}71 \\
\\
84 \\
80\end{array}$ & $\begin{array}{r}95 \\
127 \\
148\end{array}$ \\
\hline 3 & After & $\begin{array}{l}12 \\
26 \\
33 \\
44\end{array}$ & $\begin{array}{l}75 \\
55 \\
60 \\
62\end{array}$ & $\begin{array}{l}81 \\
87 \\
87 \\
86\end{array}$ & $\begin{array}{l}79 \\
53 \\
58 \\
61\end{array}$ & $\begin{array}{r}18 \\
11 \\
8\end{array}$ & $\begin{array}{l}53 \\
53 \\
56 \\
56\end{array}$ & $\begin{array}{l}58 \\
64 \\
65 \\
68\end{array}$ & $\begin{array}{l}82 \\
94\end{array}$ & 150 \\
\hline 4 & $\begin{array}{l}\text { Before } \\
\text { After }\end{array}$ & $\begin{array}{l}\text { BMT } \\
13\end{array}$ & $\begin{array}{l}78 \\
15\end{array}$ & $\begin{array}{l}84 \\
30\end{array}$ & $\begin{array}{l}89 \\
44\end{array}$ & 4 & $\begin{array}{l}78 \\
44\end{array}$ & $\begin{array}{l}104 \\
111\end{array}$ & $\begin{array}{l}90 \\
49\end{array}$ & $\begin{array}{l}110 \\
133\end{array}$ \\
\hline 5 & After & $\begin{array}{l}12 \\
24 \\
28\end{array}$ & $\begin{array}{l}64 \\
23 \\
17\end{array}$ & $\begin{array}{l}64 \\
36 \\
33\end{array}$ & $\begin{array}{l}84 \\
54 \\
44\end{array}$ & $\begin{array}{r}13 \\
6\end{array}$ & $\begin{array}{l}61 \\
40 \\
18\end{array}$ & $\begin{array}{l}77 \\
87 \\
48\end{array}$ & & \\
\hline $6 \dagger$ & After & $\begin{array}{r}6 \\
30 \\
34 \\
43\end{array}$ & $\begin{array}{l}39 \\
34 \\
59 \\
48\end{array}$ & $\begin{array}{l}61 \\
38 \\
67 \\
51\end{array}$ & $\begin{array}{l}61 \\
82 \\
77 \\
72\end{array}$ & $\begin{array}{r}26 \\
1 \\
6 \\
0\end{array}$ & $\begin{array}{l}65 \\
28 \\
42 \\
40\end{array}$ & $\begin{array}{l}70 \\
61 \\
62 \\
73\end{array}$ & $\begin{array}{l}50 \\
93 \\
93\end{array}$ & $\begin{array}{r}94 \\
172 \\
173\end{array}$ \\
\hline $7 \dagger$ & After & $\begin{array}{l}11 \\
18 \\
24\end{array}$ & $\begin{array}{l}17 \\
43 \\
39\end{array}$ & $\begin{array}{l}25 \\
48 \\
46\end{array}$ & $\begin{array}{l}60 \\
78 \\
76\end{array}$ & $\begin{array}{r}0 \\
1 \\
11\end{array}$ & $\begin{array}{l}70 \\
50\end{array}$ & $\begin{array}{r}111 \\
80\end{array}$ & 64 & 120 \\
\hline $8 \dagger$ & After & $\begin{array}{l}11 \\
12 \\
16 \\
38 \\
74\end{array}$ & $\begin{array}{l}46 \\
34 \\
84 \\
81 \\
89\end{array}$ & $\begin{array}{l}70 \\
55 \\
95 \\
90 \\
99\end{array}$ & $\begin{array}{l}52 \\
64 \\
70 \\
72 \\
75\end{array}$ & $\begin{array}{r}3 \\
12 \\
8 \\
5\end{array}$ & $\begin{array}{l}56 \\
46 \\
67 \\
46 \\
68\end{array}$ & $\begin{array}{l}76 \\
74 \\
73 \\
53 \\
70\end{array}$ & $\begin{array}{l}88 \\
91\end{array}$ & 176 \\
\hline
\end{tabular}

FEV - forced expiratory volume in one second;

VC-Vital capacity;

$\triangle \mathrm{FEV}_{1}$ - percentage change in $\mathrm{FEV}_{1}$ after bronchodilator;

TLCO-carbon monoxide transfer factor;

KOO-carbon monoxide transfer coefficient;

TLC-total lung capacity;

RV-residual volume;

*Percentage of predicted normal.

†Patients with severe aplastic anaemia before transplantation.

developing eight weeks after bone marrow transplantation. Despite resolution of the chest radiographic changes cough, wheezing, and exertional dyspnoea persisted with acute asthma like exacerbations until six months after bone marrow transplantation. Virological and bacteriological investigations were consistently negative in all three patients, and bronchodilator treatment was of no benefiit.

\section{Results}

Table 2 shows results of pulmonary function tests. No patient had respiratory symptoms or signs before bone marrow transplantation and all had normal chest radiographs. Results of pulmonary function tests performed before bcne marrow transplantation in two patients were essentially normal.

\section{PATIENTS WITH CHRONIC GRANULOCYTIC} LEUKAEMIA

In the first measurements, made 12 to 26 weeks after bone marrow transplantation, the VC was low (30-64\% predicted) in three patients (cases 1,4 , and 5). In addition, two patients (cases 1 and 5) had a low $\mathrm{FEV}_{\mathrm{l}} / \mathrm{VC}$ ratio $(<50 \%)$. All five patients had a reduced TLCO (44-66\% predicted) at this time. Subsequently the three other patients went on to develop airflow obstruction with $\mathrm{FEV}_{\mathrm{1}} / \mathrm{VC}$ ratios of $<55 \%$. There was no further fall in TLCO except in one patient (case 5). KCO was preserved except in two (cases 3 and 5).

Confirmation of airflow obstruction was provided by raised values of $R V$ in the four patients in whom it was measured and an abnormal difference $(>0.5$ BTPS) between TLC measured by body plethys- 


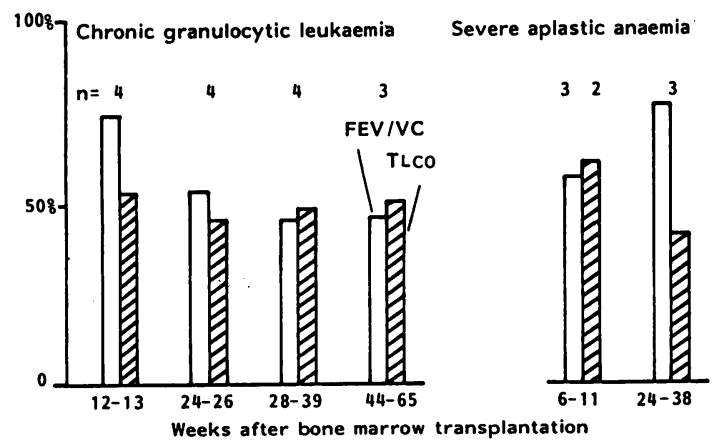

Fig 2 FEV/VC ratio (\%) () and TLCo (\% of predicted normal) (a) in patients with chronic granulocytic leukaemia and severe aplastic anaemia at different periods after bone marrow transplantation. The number of patients at the different times is shown.

mography and VA measured at maximum inspiration by helium dilution during the 10 second period of breath holding of the single breath transfer test; actual values for this difference ranged from 0.7 to 1.551 . The flow-volume curve in one patient (case 2) showed very low expiratory flow rates and a low ratio of expiratory to inspiratory flow at $50 \% \mathrm{VC}$ $(0.44 v$ normal of $>0.7)$ indicative of lower airways obstruction.

The airways obstruction was essentially irreversible; the percentage change in $\mathrm{FEV}_{1}$ after $2.5 \mathrm{mg}$ of nebulised salbutamol (table 2) ranged from 0 to $20 \%$. As the $F E V_{1}$ was very low in absolute terms ( $<35 \%$ predicted in cases 1,2 , and 5 ) the volume change was very small.

Two patients (cases 1 and 2) were smokers (table 1) but gave up just before bone marrow transplantation.

\section{PATIENTS WITH SEVERE APLASTIC ANAEMIA}

In the first measurements made six to 11 weeks after bone marrow transplantation in those patients VC was reduced, severely so in one (case 7); the ratio of $\mathrm{FEV}_{1}$ to VC was low (52-61\%) and TLCO was reduced. Subsequently, VC improved in two patients (cases 7 and 8 ) and the $\mathrm{FEV}_{\mathrm{l}} / \mathrm{VC}$ ratio became nearly normal $(72-76 \%)$ in all three. The improvement in $\mathrm{VC}$ and $\mathrm{FEV}_{1} / \mathrm{VC}$ ratio was not accompanied by an improvement in TLCO. As in the patients with chronic granulocytic leukaemia, KCO was relatively well preserved. RV was raised in two patients (cases 6 and 8), and they had a large difference between TLC and VA $(1 \cdot 3-1 \cdot 71)$. One of them (case 6) showed some reversibility in the first measurement after bone marrow transplantation but not subsequently. The other two showed no reversibility.

Figure 2 shows the discordance between airflow obstruction in terms of $\mathrm{FEV}_{1} / \mathrm{VC}$ ratio and TLCO as a function of time for the chronic granulocytic leukaemia and severe aplastic anaemia groups. In patients with chronic granulocytic leukaemia the $\mathrm{FEV}_{1} / \mathrm{VC}$ ratio at the onset of respiratory symptoms was relatively normal at a time when the TLCO was already reduced; subsequently the $\mathrm{FEV} / \mathrm{VC}$ ratio fell. In contrast, in the patients with severe aplastic anaemia the earliest measurements after bone marrow transplantation showed reduction in the $\mathrm{FEV}_{1} / \mathrm{VC}$ ratio and TLCO but the $\mathrm{FEV}_{1} / \mathrm{VC}$ ratio subsequently rose.

\section{Discussion}

INCIDENCE OF THE PULMONARY SYNDROME The incidence of this pulmonary syndrome (table 3 ) in our practice was at least $13 \%$ (eight out of 64 patients surviving three or more months after bone marrow transplantation). It may have been more common after bone marrow transplantation for chronic granulocytic leukaemia than for severe aplastic anaemia (18\% v $8 \%$ respectively), but the numbers were too small to draw firm conclusions.

The TLCO was reduced after transplantation in all the patients (fig 2) but the airflow obstruction differed in timing and outcome in the two groups; the patients with chronic granulocytic leukaemia presented with a low TLCO without much obstruction

Table 3 Relation of severity of graft versus host disease (GVHD) to incidence of airways obstruction in 28 patients transplanted for chronic granulocytic leukaemia $(C G L)$ and 36 patients transplanted for severe aplastic anaemia $(S A A)$ who survived at least three months after bone marrow transplantation (BMT)

\begin{tabular}{|c|c|c|c|c|}
\hline \multirow[t]{2}{*}{ Chronic GVHD } & \multicolumn{2}{|c|}{$C G L$ patients after $B M T$} & \multicolumn{2}{|c|}{$S A A$ patients after $B M T$} \\
\hline & $n$ & No with symptomatic airflow obstruction & $n$ & No with symptomatic airflow obstruction \\
\hline $\begin{array}{l}\text { None } \\
\text { Mild } \\
\text { Moderate } \\
\text { Severe } \\
\text { Total }\end{array}$ & $\begin{array}{r}9 \\
7 \\
4 \\
8 \\
28\end{array}$ & $\begin{array}{l}0 \\
0 \\
0 \\
5 \\
5(18 \%)\end{array}$ & $\begin{array}{r}24 \\
4 \\
7 \\
1 \\
36\end{array}$ & $\begin{array}{l}0 \\
2 \\
1 \\
0 \\
3(8 \%)\end{array}$ \\
\hline
\end{tabular}


but later developed a progressive obstructive defect, whereas the patients with severe aplastic anaemia presented with airflow obstruction that subsequently regressed. It is therefore likely that the pathogenesis of the airways obstruction in these two groups was different.

\section{THE NATURE OF THE AIRFLOW OBSTRUCTION}

Various diagnoses were considered but excluded on the basis of the clinical and functional findings. The overall picture was unlike asthma. There was virtually no response to bronchodilators, and no patient had a history suggestive of asthma before bone marrow transplantation, though one had hay fever and another childhood eczema and a family history of asthma. Skinprick test reactions were negative in four patients. One patient had asthma like attacks (case 8 ) but did not show reversibility. Moreover, the lack of appropriate history before bone marrow transplantation and the speed of onset of respiratory symptoms argue against chronic obstructive lung disease. The absence of sputum is against bronchiectasis. Characteristic radiological features of bronchiectasis and emphysema were absent. Three of the eight patients were smokers (table 1), and, though this may have been an aggravating factor, their clinical course and functional changes resembled those of the non-smokers.

The clinical picture in these patients was similar to that referred to as obliterative bronchiolitis. Obliterative bronchiolitis is characterised by rapidly progressive severe airways obstruction in the absence of chronic bronchitis. ${ }^{15}$ It has been described after viral infections in children, ${ }^{16}$ after exposure to nitrogen dioxide in adults, ${ }^{17}$ and in association with connective tissue disorders, ${ }^{18}$ including rheumatoid arthritis ${ }^{19}$ and Sjögren's syndrome..$^{20}$ Generalised necrotising obliterative bronchiolitis has also been reported in one patient with graft versus host disease. ${ }^{9}$ The viral and toxic forms are generally associated with an acute illness after exposure to the initiating agent, followed one to three weeks later by the onset of progressive breathlessness with nodular shadows or an appearance similar to pulmonary oedema on the chest radiograph. The response to corticosteroids was usually reasonably good.

The clinical picture in the patients with chronic granulocytic leukaemia fitted quite well with this condition. This diagnosis was also supported by findings from open lung biopsy in one patient (fig 1). Resolution of airflow obstruction, as occurred in the patients with severe aplastic anaemia, is unusual in obliterative bronchiolitis and the importance of this finding is not clear.
PREVIOUS REPORTS OF AIRFLOW OBSTRUCTION AFTER BONE MARROW TRANSPLANTATION

Airflow obstruction after bone marrow transplantation has been mentioned only rarely in published reports. Shulman et al studied 20 patients with chronic graft versus host disease and noted wheezing in six and abnormal lung function test results, either restrictive or obstructive, in 10 of 14 patients tested; no details of pulmonary function were given. ${ }^{7}$ Link $e t$ al reported two cases of progressive airways obstruction, one after bone marrow transplantation for severe aplastic anaemia ( $3 \mathrm{~Gy}(300 \mathrm{rad})$ total body irradiation given) and the other after bone marrow transplantation for acute myeloid leukaemia (10 Gy (1000 rad) total body irradiation given) ${ }^{8}$ Both developed acute and chronic graft versus host disease and a syndrome of cough and dyspnoea that progressed until their deaths from viral infections 10 to 14 months after bone marrow transplantation, respectively. Lung function tests were reported to have shown an obstructive pattern, but again details were not presented. Postmortem examination was carried out in the patient with acute myeloid leukaemia and showed obstruction of airways with exudate and necrotic material. Roca $e t a l^{9}$ reported on a patient who received a bone marrow transplantation for severe aplastic anaemia (but presumably did not receive total body irradiation); ${ }^{9}$ he developed chronic graft versus host disease and a syndrome resembling that of our patients with chronic granulocytic leukaemia with similar pulmonary function data. He died 14 months after bone marrow transplantation and percutaneous lung biopsies post mortem showed generalised necrotising obliterative bronchiolitis. Ralph et al recently described four patients with progressive airflow obstruction after bone marrow transplantation; ${ }^{10}$ three of these patients underwent transplantation for severe aplastic anaemia and presumably did not therefore 3 receive total body irradiation; the fourth patient had $\delta$ acute leukaemia and would have received total body irradiation. The clinical picture in these cases and the 0 histopathology of the lung biopsy specimen from case 2 in their series closely resembled the patients described in our report.

POSSIBLE ROLE OF TOTAL BODY IRRADIATION In the group with chronic granulocytic leukaemia the $\mathrm{C}$ initial low value of TLCO would be consistent with radiation damage. ${ }^{22}$ Nevertheless, there were no radiographic changes that could be attributed to radi- $\stackrel{\Phi}{\mathscr{Q}}$ ation fibrosis, and there was a similarly low TLCO in the patients with severe aplastic anaemia, two of $-{ }^{-}$

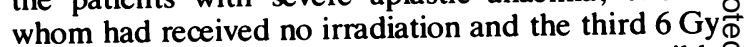
(600 rad) only. Radiation damage would be a possible $\frac{\rho}{\mathbb{P}}$ explanation for the initial discrepancy in $\mathrm{FEV}_{1} / \mathrm{VC}^{\mathrm{O}}$ 
ratio and TLCO in the group with chronic granulocytic leukaemia.

\section{POSSIBLE ROLE OF INFECTION}

The patients with severe aplastic anaemia suffered acute onset of respiratory symptoms, and patchy shadowing was seen on their chest radiographs; infection may therefore have been the triggering factor, although no organisms were isolated and viral antibody titres remained negative. The patients with chronic granulocytic leukaemia showed more gradual onset of symptoms with no obvious infective episodes in the early stages, although recurrent chest infections later became a problem in one (case 5), who finally succumbed to necrotising aspergillosis.

ASSOCIA TION WITH GRAFT VERSUS HOST DISEASE All eight patients had acute and chronic graft versus host disease. The association between chronic graft versus host disease and airways obstruction was particularly strong in the group with chronic granulocytic leukaemia; of a total of 28 patients who, after undergoing transplantation for chronic granulocytic leukaemia, survived for more than three months, eight developed severe graft versus host disease and five of those eight developed airways obstruction and are reported on here (table 3 ). Of the three who did not develop airways obstruction, only one had multisystem graft versus host disease; in the other two cases graft versus host disease was confined to the liver. The association with graft versus host disease was less distinct for the patients undergoing transplantation for severe aplastic anaemia.

\section{PATHOGENESIS}

The pathogenesis of this syndrome is uncertain, though the lymphocytic infiltration of terminal bronchioles as seen in one patient (fig 1 ) would be consistent with graft versus host disease. 6 The role of other factors, such as treatment of the leukaemia with busulphan during the chronic phase, the conditioning with cyclophosphamide, irradiation before bone marrow transplantation, and the immunosuppressive drugs or infection after bone marrow transplantation, remains to be determined.

\section{TREA TMENT}

The effect of corticosteroid treatment is difficult to assess as it was used for graft versus host disease in all patients in variable doses and for variable periods. In one patient (case 7), however, respiratory symptoms occurred after stopping corticosteroid treatment and improved on restarting, and another patient (case 2) showed gradual deterioration of symptoms as corticosteroid treatment was slowly withdrawn but had considerable symptomatic benefit subsequently from a large increase in her steroid dose. Bronchodilators have not given symptomatic benefit to any patient. Antibiotics may have been important in the improvement seen in the patients with severe aplastic anaemia.

\section{PROGNOSIS}

The prognosis appears to differ greatly in the two groups of patients whose data have been presented. Airflow obstruction resolved in the patients with severe aplastic anaemia. Of the patients with chronic granulocytic leukaemia, two died (one of a respiratory cause) and three survived with appreciable airflow obstruction 11,15 , and 20 months after bone marrow transplantation.

SEW was supported by the SG Warburg Voluntary Trust. JMH was supported by the Leukaemia Research Fund.

\section{References}

1 Camitta BM, Thomas ED, Nathan DG, et al. Severe aplastic anemia: a prospective study of the effect of early marrow transplantation on acute mortality. Blood 1976;48:64-70.

2 Goldman JM, Baughan ASJ, McCarthy DM, et al. Marrow transplantation for patients in the chronic phase of chronic granulocytic leukaemia. Lancet 1982;ii:623-5.

3 Neiman PE, Reeves W, Ray G, et al. A prospective analysis of interstitial pneumonia and opportunistic viral infection among recipients of allogeneic bone marrow grafts. J Infect Dis 1977;136:754-67.

4 Bortin M, Kay H, Gale RP, Rimm AA. Factors associated with interstitial pneumonitis after bone marrow transplantation for acute leukaemia. Lancet 1982;ii:4379.

5 Barrett A. Total body irradiation (TBI) before bone marrow transplantation in leukaemia: a cooperative study from the European Group for Bone Marrow Transplantation. Br J Radiol 1982;55:562-7.

6 Beschorner WE, Saral R, Hutchins GM, Tutschka PJ, Santos GW. Lymphocytic bronchitis associated with graft-versus-host disease in recipients of bone marrow transplants. N Engl J Med 1978;299:1030-6.

7 Shulman HM, Sullivan KM, Weiden PL, et al. Chronic graft-versus-host syndrome in man. A long-term clinico-pathological study of 20 Seattle patients. Am J Med 1980;69:204-17.

8 Link H, Reinhard U, Niethammer D, Kruger GRF, Waller HD, Wilms K. Obstructive ventilation disorder as a severe complication of chronic graft-versus-host disease after bone marrow transplantation. Exp Hematol 1982; suppl 10:92-3.

9 Roca J, Granena A, Rodriguez-Roisin R, Alvarez P, Agusti-Vidal A, Rozman C. Fatal airways disease in an adult with chronic graft-versus-host disease. Thorax 1982;37:77-8.

10 Ralph DD, Springmeyer SC, Sullivan KM, Hackman RC, Storb R, Thomas ED. Rapid progressive air-flow obstruction in marrow transplant recipients: possible association between obliterative bronchiolitis and chronic 
graft-versus-host disease. Am Rev Respir Dis 1984;129:641-4.

11 Thomas ED, Storb R, Clift RA, et al. Bone marrow transplantation. N Engl J Med 1975;292:832-4, 895902.

12 Quanjer PLH, ed. Standardized lung function testing. Report of Working Party for European Community for Coal and Steel. Bull Europ Physiopathol Respir 1983;19 (suppl 5):7-10.

13 Bradley J, Bye C, Hayden SP, Hughes DTD. Normal values of transfer factor and transfer coefficients in healthy males and females. Respiration 1979;38:221-6.

14 Cotes JE, Dabbs JM, Elwood PC, Hall AM, McDonald $A$, Saunders MJ. Iron-deficiency anaemia: its effect on transfer factor for the lung (diffusing capacity) and ventilation and cardiac frequency during submaximal exercise. Clin Sci 1972;42:325-35.

15 Turton CW, Williams G, Green M. Cryptogenic obliterative bronchiolitis in adults. Thorax 1981;36:805-10.
16 Wohl MEB, Charnick V. Bronchiolitis. Am Rev Respir Dis 1978;118:759-81.

17 Ramirez RJ, Dowell AR. Silo-filler's disease: nitrogen dioxide-induced lung injury. Ann Intern Med 1971;74:569-76.

18 Epler GR, Snider GL, Gaensler EA, Cathcart ES, Fitzgerald MX, Carrington CB. Bronchiolitis and bronchitis in connective tissue disease. JAMA 1979;242:528-32.

19 Geddes DM, Corrin B, Brewerton DA, Davies RJ, Turner-Warwick M. Progressive airways obliteration in adults and its association with rheumatoid disease. $Q J$ Med 1977;46:427-44.

20 Newball HH, Brahim SA. Chronic obstructive airways disease in patients with Sjögren's syndrome. Am Rev Respir Dis 1977;115:295-304.

21 Anonymous. Obliterative bronchiolitis [editorial]. Lancet 1982;i:603-4.

22 Gross NJ. Pulmonary effects of radiation therapy. Ann Intern Med 1977;86:81-92. 